\title{
Decolonising knowledge production on Africa: why it's still necessary and what can be done
}

\author{
Gordon Crawford, Zainab Mai-Bornu and Karl Landström
}

Abstract: Contemporary debates on decolonising knowledge production, inclusive of research on Africa, are crucial and challenge researchers to reflect on the legacies of colonial power relations that continue to permeate the production of knowledge about the continent, its peoples, and societies. Yet these are not new debates. Sixty years ago, Ghana's first president and pan-Africanist leader, Dr Kwame Nkrumah, highlighted the importance of Africa-centred knowledge. Similarly, in the 1980s, Claude Ake advocated for endogenous knowledge production on Africa. But progress has been slow at best, indicated by the enduring predominance of non-African writers on African issues within leading scholarly journals. Thus, we examine why decolonisation of knowledge production remains so necessary and what can be done within the context of scholarly research in the humanities and social sciences. These questions are addressed at two levels, one more practical and one more reflective. At both levels, issues of power inequalities and injustice are critical. At the practical level, the asymmetrical power relations between scholars in the Global North and South are highlighted. At a deeper level, the critiques of contemporary African authors are outlined, all contesting the ongoing coloniality and epistemic injustices that affect knowledge production on Africa, and calling for a more fundamental reorientation of ontological, epistemological, and methodological approaches in order to decolonise knowledge production.

Keywords: Decolonisation, knowledge production, Nkrumah, power asymmetries, epistemic injustice.

(C) The author(s) 2021. This is an open access article licensed under a

Creative Commons Attribution-NonCommercial-NoDerivs 4.0 Unported License 


\section{Introduction}

The decolonisation of knowledge production has become a major subject for discussion both within academia and in society at large in recent years (Smith 1999, Arowosegbe 2016, Mbembe 2016, Nyamnjoh 2017, Ndlovu-Gatsheni 2018, Santos 2018). While the decolonisation agenda has been part of postcolonial studies for at least twenty-five years, the contemporary focus was given a major impetus by the '\#Rhodes must fall' movement in South Africa in 2015. This commenced at the University of Cape Town in March 2015 with students (successfully) calling for the removal of the statue of the imperialist Cecil Rhodes, with protests then spreading throughout South Africa and worldwide, including the Oxford 'Rhodes must fall' movement, and demands broadening to calls for the decolonisation of higher education. Yet, these are not new debates. Sixty years ago, Ghana's first president and pan-Africanist leader, Dr Kwame Nkrumah, highlighted the importance of Africa-centred knowledge when he established the Institute of African Studies at the University of Ghana. In the early 1980s, the Nigerian political scientist Claude Ake advocated for endogenous knowledge production on Africa. However, progress since the earlier independence period has been slow at best.

We focus here on the implications of the current decolonisation debates for research and knowledge production on Africa. We outline why decolonisation of knowledge production remains so necessary and explore what can be done within the context of scholarly research in the humanities and social sciences. These questions are addressed at two levels, one more practical and one more reflective. At both levels, issues of power inequalities and injustice are critical. At the more concrete level, the asymmetrical power relations between scholars in the Global North and South are stark. These include the predominance of non-African writers on African issues in academic journals, the lack of direct access to research grant funding by African scholars, and their difficulties in even accessing academic work by African colleagues in non-open-access publications. Measures to address such asymmetries, and thus to assist with decolonisation in research and publishing, are outlined. Yet these are not sufficient. The power asymmetries are symptomatic of a deeper injustice and malaise concerning the type of knowledge produced about Africa, and its peoples and societies, that stems from the endurance of Eurocentric epistemologies. The critiques of a number of contemporary African authors are outlined, all contesting the ongoing coloniality and epistemic injustices that affect knowledge production on Africa, and calling for a more fundamental reorientation of ontological, epistemological, and methodological approaches in order to decolonise knowledge production.

The article proceeds in five parts. Following this short introduction, the second part looks at historical precedents in decolonising knowledge production on Africa 
and their relative success and failure. The third part then explores why decolonising knowledge is still necessary, examining both scholarly privilege and injustice between Africa-based academics and those in the Global North, as well as the deeper issues of coloniality and epistemic injustice. The fourth part considers what can be done to pursue a decolonisation agenda, including how to counter scholarly power asymmetries as well as how to make progress towards greater epistemic justice. Finally, a brief summary conclusion is provided.

\section{Historical precedents on decolonising knowledge production}

Current calls to decolonise knowledge production on Africa are related to colonial practices of power and domination, and indicate that sixty years of independence has not radically altered those relations of power between higher education institutions and individuals in the Global South and North. Legacies still exist and the enduring predominance of non-African writers on African issues within leading scholarly journals remains striking. As Jeremiah Arowosegbe (2016: 324) remarks, this dominance suggests that 'the production of knowledge on Africa in the humanities and social sciences takes place within historically determined as well as ongoing asymmetrical relations of power'. Or, as Amina Mama (2007: 4, cited in Briggs \& Weathers 2016: 487) put it more bluntly, 'Most of that which is received as knowledge about Africa is produced in the West.' Yet, while contemporary calls for the decolonisation of knowledge production, and of higher education more generally, resound around universities with increasing vociferousness in both the Global South and North, it is useful to recall that these are not new calls.

\section{Kwame Nkrumah and postcolonial knowledge production}

Dr Kwame Nkrumah, independence leader, first president of Ghana, anti-imperialist, and pan-Africanist visionary, sought to undertake the 'great task of promoting scholarship and research into Africa's history, culture, thought and resources' (Nkrumah 1973: 206). Shortly after independence in Ghana in 1957, he took two important initiatives that effectively promoted postcolonial knowledge production on Africa: the establishment of the Institute of African Studies at the University of Ghana in 1961; and the invitation to the African-American scholar Dr W.E.B. Du Bois to undertake the compilation of an Encyclopaedia Africana in Ghana (Allman 2013).

The Institute of African Studies was established with a specifically decolonial mandate. In Nkrumah's own words at the official opening of the Institute in 1963, its purpose was to study: 
the history, culture and institutions, languages and arts of Ghana and of Africa in new African centred ways - in entire freedom from the propositions and pre-suppositions of the colonial epoch, and from the distortions of those ... who continue to make European studies of Africa the bases of this new assessment. (speech by Dr Kwame Nkrumah, 25 October 1963, cited in Allman 2013: 183, emphasis added)

This African-centred perspective was also articulated by Nkrumah in his speech at the First International Congress of Africanists held at the University of Ghana on 12 December 1962. Criticising European and American writing on Africa for its use in justifying slavery and colonialism and for its denial of African history that was not linked to European contact (Nkrumah 1973: 208-9), he called on Africanist scholars 'to work for a complete emancipation of the mind from all forms of domination, control and enslavement' (1973: 212).

Nkrumah's explicitly decolonial perspective was similarly emphasised by the Institute of African Studies' first director, Thomas Hodgkin, stating that:

The next ten years may well be decisive for the African Revolution: hence it is precisely during this period that it is essential to develop within Africa, Centres of African Studies that are liberated ... from conventional Western presuppositions. (Ghanaian Times, 21 November 1964 , cited in Allman 2013: 190)

The historical significance of this new approach to knowledge production on Africa was evident, as noted by Jean Allman (2013: 192):

In its [the Institute's] vision and in its praxis, it was transcending, in bold, innovative ways, older paradigms of knowledge production. ... Nkrumah and the Institute's faculty considered it to be in the vanguard of a pan-African movement to re-imagine, to re-invent how knowledge about Africa was produced, interpreted, and circulated.

Nkrumah's second initiative was to invite Dr W.E.B. Du Bois, US sociologist, historian, civil rights activist, and fellow pan-Africanist, to relocate to Ghana to work on his Encyclopaedia Africana project. This was intended, in Nkrumah's words, 'to contain full and up-to-date information about Africa and the African people' (1973: 206). It was housed within the Ghana Academy of Learning (later renamed the Ghana Academy of Sciences) (Allman 2013: 193-5), where Du Bois spent the last years of his life (1961-3). The legacy of this initiative remains today in Accra in the form of the W.E.B. Du Bois Centre for Pan African Culture. ${ }^{1}$

These two initiatives in the early 1960s, closely associated with Nkrumah's panAfricanist vision, were highly significant. As expressed by Allman (2013: 193):

${ }^{1}$ http://webduboiscentreaccra.ghana-net.com/index.html 
In the history of knowledge production about Africa, this constituted an extraordinary moment ...- a moment bursting with possibilities, in which engaged and rigorous debate, Africa-centered and Africa-based, was the prerequisite, no epistemic paradigm was hegemonic, and 'African Studies' was envisioned as the site for a full re-imagining of higher education in an African postcolonial world.

But, as is well known, Nkrumah was deposed in a military coup in February 1966, and with his overthrow this moment of decolonial knowledge production faltered, as it had been largely reliant on Nkrumah's drive. However, as Allman (2013: 193) sums up, 'But for a brief moment, anyway, the grounds of knowledge production about Africa had certainly shifted dramatically.'

\section{Claude Ake and calls for the decolonisation of the social sciences in Africa}

Moving forward to the late 1970s and early 1980s, in his book entitled Social Science as Imperialism, the Nigerian political scientist Claude Ake claimed that 'mainstream Western social science scholarship on Africa and other developing countries amounts to imperialism' (1982: 124). ${ }^{2}$ In his words, the book is 'a study of one of the most subtle and pernicious forms of imperialism-imperialism in the guise of scientific knowledge' (1982: xiii). His critique is particularly directed at the political development theory that was part of the dominant modernisation paradigm, but also extended to sociology and economics (1982: ch.4). He contends that Western scholarship is 'an important tool for controlling Third World perceptions of their world and their problems and eventually Third World behaviour' (1982: 139, emphasis added), although he acknowledged that Western scholars are not necessarily conscious that their work serves imperialism (1982: 124). Arguing along similar lines to Edward Said (1978) in Orientalism, Ake notes how 'the "problems" of Third World societies' are explained 'in terms of their lack of the characteristics of Western societies' (1982: 148, emphasis added). In his view, the teleological thinking inherent in Western social science, coupled with its Eurocentric bias, leads to the presentation of Western societies as 'advanced or even the ideal', while developing societies are seen as 'at the lower ends of the developmental continuum' (1982: 125-7). Insofar as Africa-based social scientists accept these theories, 'they in effect acknowledge their own inferiority and the superiority of the West' (1982: 141). Thus, in highlighting the imperialist outcomes, Ake notes that: 'The West is able to dominate the Third World not simply because of her military and economic power, but also because she has foisted the idea of development on the Third World' (1982: 141).

\footnotetext{
${ }^{2}$ Ake (1982: xiii) makes an exception of the Marxist tradition, though without a full explanation.
} 
In Arowosegbe's (2008a, 2008b) discussion of Claude Ake's contribution to social science and knowledge production in Africa, he notes the parallel drawn by Ake between the colonial/neocolonial division of labour in the economic sphere and that in the production of knowledge. In Arowosegbe's words, 'just as Africa has been reduced to raw material production and Europe specializes in the production of capital goods and finished products, there is also the ideological reduction of the continent to a source from which data are generated and exported to Europe for advancing the frontiers of knowledge' (2008b: 346, citing Ake 1982). In other words, Africa-based scholars are exploited to collect and export the raw (empirical) data to be turned into finished knowledge products by Africanist academics in universities in the North. The persistence of this 'international intellectual division of labour' in the 21st century has been noted by Paul Tiyambe Zeleza (2002: 21): 'African universities and social scientists continue to import appropriate packages of "universal" theory and, at best, export empirical data.' In his view, this 'culture of imported scientific consumerism' was established during colonialism, spread after independence, and endures to this day (2002: 21). Zeleza relates this to what Paulin Hountodji (1997) called 'theoretical extraversion', a 'persistence of the external-gazing structures and ideologies of colonialism' (2002: 21).

Decades earlier, Ake (1982) had noted the adverse implications of this colonial division of labour for knowledge production on Africa. In his view, the dominance of Western scholarship and the inappropriate use of Western theories to explain African social phenomena led to wrongly generalising from one context to another, with inadequate explanations of social realities on the continent. Other African writers made similar critiques. Valentin Y. Mudimbe $(1988,1994)$ further elucidated the epistemological consequences of these unequal and colonial power relations by demonstrating how Europe invented and represented Africa and how the colonisers shaped African world-views. Mahmood Mamdani (1996) noted the problematic outcomes, in studies of African phenomena, of African experiences and history being constantly compared to European and North American counterparts. In discussing African politics and democracy, Mamdani (1992: 2228) argued that this has led to solutions to African problems being drawn from contexts which have little in common with contemporary realities in Africa, rather than being drawn from the African context in which they arose.

In seeking an alternative social science, Ake advocated for endogenous knowledge production on Africa. As editor-in-chief of the first issue of the African Journal of Political Economy, he stated that 'unless we strive for endogenous development of science and knowledge we cannot fully emancipate ourselves' (1986: III). As noted by Arowosegbe (2008a: 27), Ake stood for 'the development of a social science scholarship ... [that is] rooted in its culture and locale'. This makes sense, of course. African 
scholars are in a much better position to understand social phenomena in their own countries and localities. Kwesi Yankah made a similar point, one that supported the call for endogeneity, when he commented on the oftentimes poor and inadequate knowledge produced about Africa by Western academics, and noted in contrast that researchers based within Africa have a 'deep privileged knowledge and analysis of ground material' (Yankah 1995: 10, cited in Briggs \& Weathers 2016: 470).

\section{Why is decolonising knowledge production still necessary?}

Despite these earlier precedents in the postcolonial period, and after more than six decades of political independence in most of sub-Saharan Africa, knowledge production on Africa remains characterised by stark asymmetries of power. As Arowosegbe (2016: 324) noted, these are both 'historically determined', with their origins in colonial relations, and remain 'ongoing' to this day. Some of such asymmetries of power are visible and direct; others are more hidden and indirect. Therefore, the decolonisation of knowledge remains necessary from a justice perspective. Enduring injustice takes different forms, and we explore two here. First, there is the injustice in terms of unequal access to resources and opportunities between scholars from the Global North and South. Second, there is the key issue of epistemic injustice and the question of 'whose knowledge counts', with many voices and perspectives remaining unheard and unrecognised, especially those from less powerful institutions and marginalised communities. We examine these two aspects of enduring injustice in turn.

\section{Scholarly privilege and injustice}

The respective privilege and disadvantage accorded to scholars of African Studies in the Global North and South, respectively, remains very evident. One manifestation of such power relations was highlighted by Ryan Briggs and Scott Weathers (2016). They analysed all research articles in African Affairs and Journal of Modern African Studies, top-ranked Africanist journals in the English-speaking world, over a period of twenty-one years (1993 to 2013). Their findings were that Africa-based authors were publishing not only a small proportion of articles, but a declining share in both journals. Despite year-on-year fluctuations, the percentage of articles by Africa-based authors had declined overall from around $25 \%$ in the early 1990 s to $15 \%$ by 2013 (Briggs \& Weathers 2016: 474-5). Since 2005, there had been no year in which Africabased authors contributed more than $20 \%$ of articles in either journal. In terms of gender, the findings were even more blunt. Most articles written by Africa-based 
academics were by men, with Africa-based women publishing only twenty-one single-authored articles out of 935 articles in the database (2016: 474). In seeking to explain this, Briggs and Weathers noted that submission rates from Africa-based authors had actually increased, but acceptance rates were low and declining. They suggested two possible explanations for this, while noting that they had no means to empirically evaluate such propositions and that future research is needed. The first explanation is editorial gatekeeping and reviewer bias, with the assumption that the majority of reviewers are from Global North institutions and could display implicit bias (2016: 477). The second possible explanation for declining acceptance rates is low quality of submissions. Briggs and Weathers stated that this was the most common explanation proffered in informal conversations during the research. If there is any truth to this, then they suggest that it relates to the increased pressure on academics in African universities with rising student numbers coupled with declining levels of state support for tertiary education in many countries. As they state, the 'financial situation of African universities is likely to be part of the story' (Briggs \& Weathers 2016: 478), with less time and opportunities for academics to undertake research and writing.

Peace Medie \& Alice Kang (2018) undertook research to ascertain the representation of Global-South-based scholars in journals in the area of women, gender, and politics, a literature that has grown hugely in the last three decades, including research on Global South countries. The results were quite alarming. Of the 947 articles published in four leading European and North American journals between 2008 and 2017, less than 3\% were by scholars from Global South institutions. Of the four journals, the highest proportion was in the International Feminist Journal of Politics, yet even here less than $5 \%$ of articles were authored by a researcher at a Southern institution. In seeking to explain why Global South scholars are marginalised in this way, one factor particular to Africa pertains to the adoption of structural adjustment policies by African governments in the 1980s and the consequent "hollowing out of many African universities, leading to reduced funding for research and training, poorly stocked libraries, low salaries, and heavy teaching loads' (Medie \& Kang 2018: 44, citing Mama, 2002; Zeleza, 2003). However, this does not provide a full explanation. Medie \& Kang (2018: 38) noted that previous feminist critiques in the 1980s and 1990s had highlighted unequal global power relations, ones that stemmed from colonialism:

Critical feminists, including postcolonial feminists, African feminists and South Asian feminists, writing in the 1980s and 1990s argued that approaches to the study of women and gender in the Global South adopted by white Western feminists were steeped in and reinforced unequal global power relations ... .

And they conclude that the ongoing under-representation of scholars in the Global South continues to 'demonstrate the hegemony of Western gender politics scholarship 
and reinforces the power disparity in knowledge production between the North and South' (Medie \& Kang 2018: 38).

Another significant aspect of the asymmetrical power relations between scholars in the Global North and South has been access to research funds. The sources of such funds are mainly Western governments and corporate foundations, and eligibility to apply is often restricted, especially to national government research council funds. Of course, research on countries in Africa has been a key focus of many funders, and this has required African 'partners'. While there may be good intent on the part of the Global North researchers to implement equal working relationships with their 'Southern partners', there are still enduring dimensions of power and privilege. Chisomo Kalinga (2019) provides insight into the complexity, and issues of navigating global research partnerships in the Global South as an indigenous scholar. She highlights a wide range of troubling expectations and practices from her own experiences that tend to reinforce the power of those with the funding. African staff are often pressured to keep projects running despite the challenges of working with 'research fatigued' communities who never seem to benefit directly from the research. Research frameworks and timelines clash with trust-building processes and, due to the constraints of contracts and deadlines, many external research partners are often too impatient to understand the social codes that govern the relationship between the indigenous researchers, research participants, and communities. Indigenous staff have to withstand the worst of the discontent and the aggression, stemming from a history of exploitation, power inequality, racism, and unjust income distribution. In Kalinga's view, there is a lot of potential in multi-country collaboration, but one has to take seriously the negative effects that the unequal power dynamics between the Global North and Global South systematically have on African scholars. Kalinga (2019: 272) suggests that 'these grants should ideally have forums where African researchers and academics are given platforms to be authoritative sources of and experts on their cultures and communities'. She calls for equity in collaboration where the cultural concerns and constraints of Global South partners are not suppressed by their Global North counterparts.

\section{Coloniality and epistemic injustice}

The asymmetries highlighted here, such as the predominance of non-African writers on African issues and the division of labour and unequal terms of trade between African and Global North researchers, are but symptoms of a deeper injustice and malaise that stems from what Sabelo Ndlovu-Gatsheni (2013) describes as the 'myths of decolonization' and the continued impact of the 'colonial matrix of power'. In his view, the end of direct colonial rule did not lead to an independent African 
postcolonial world, but instead to a 'postcolonial neocolonized world'. Influenced by the critical coloniality perspective of radical Latin American authors, such as Ramón Grosfuegel (2007) and Nelson Maldonado-Torres (2007), Ndlovu-Gatsheni defines the concept of 'coloniality' as different from colonialism. Coloniality refers to 'the longstanding patterns of power that emerged from colonialism and continue to define culture, labour, intersubjective relations and knowledge production, long after the end of direct colonialism. It is that continuing dominating phenomenon that survived colonialism' (2013: 16). He further states that 'Africans have breathed and lived coloniality since their colonial encounters and it continues to shape their everyday life today' (2013: 16). In terms of knowledge production, Ndlovu-Gatsheni notes that coloniality takes different forms and is inclusive of the coloniality of knowledge which 'addresses the epistemological questions of how colonial modernity interfered with African modes of knowing, social meaning-making, imagining, seeing and knowledge production, and their replacement with Eurocentric epistemologies' (2013: 8, citing Escobar 2007). In effect, 'Euro-American hegemonic knowledge [has] banished alternative epistemologies from Africa and other parts of the Global South' (2013:4).

In recent work, Ndlovu-Gatsheni (2020) situates unequal power relations in knowledge production within broader global structures driven by dominant neoliberalism. He argues that knowledge was corporatised and commercialised through neoliberal structural changes and the adoption of neoliberal philosophies in the wake of the Washington Consensus, a transformation that has led other scholars such as Mamdani $(2007,2011)$ to note that the university has become a marketplace. Similarly, Francis Nyamnjoh (2004) has argued that education in Africa is the victim of a Western epistemological export that has taken the form of science as ideological hegemony. Education in Africa has been modelled after educational institutions in the West with the aim of being competitive internationally with little regard for domestic needs and interests. This has led to the devaluation of African epistemology, agency, and value systems and to an internalised sense of inadequacy (Nyamnjoh 2012). Nyamnjoh (2004) argued that, if Africa wants to be part of global conversations on scholarship and the role of universities, then it would only be appropriate to do so on its own terms and with the interests of ordinary Africans as a guiding principle. In a later paper, he further argued that African universities in their attempts to decolonise university education have managed to significantly Africanise their personnel but not their curricula, epistemologies, or pedagogical structures in a systematic or productive manner (Nyamnjoh 2019). The Western traditions of knowledge production and the epistemologies that inform it have hardly been addressed in any meaningful or transformative manner (Nyamnjoh 2019). He proposes that any serious attempts at creating inclusive African universities that embrace African traditions of knowing and knowledge production would require looking outside of the academy in its current 
configuration. This would include taking the cosmologies, ontologies, and lived experiences of Africans seriously and to embrace these in the interest of a more relevant scholarship (Nyamnjoh 2012, 2019).

This notion of epistemic hegemony is closely related to discussions of 'epistemic injustice'. The philosopher Miranda Fricker (2007) is largely credited with the introduction of this concept which pertains to a distinctively epistemic kind of injustice that fundamentally consists of a wrong done to someone specifically in their capacity as a knower (Fricker 2007:1). It was later defined as 'those forms of unfair treatment that relate to issues of knowledge, understanding, and participation in communicative practices' (Kidd et al. 2017: 1). As a concept, epistemic injustice has been widely applied in different spheres, including to issues of decolonising knowledge production.

Writing from the Indian context, Rajeev Bhargava (2013) made the direct link between the epistemic dimension of colonial oppression and the notion of epistemic injustice. He distinguishes epistemic injustice from other ongoing forms of injustice perpetrated by the colonising states, such as political and economic injustices. Bhargava (2013) adopts a slightly different conception of epistemic injustice than the Frickerian conception. He argues that epistemic injustice occurs when the concepts and categories through which a people understand themselves and their world are either replaced or negatively affected by the categories and concepts of the colonisers. These concepts and categories constitute epistemic frameworks, historically generated and collectively sustained systems of meaning by which members of a group make sense and evaluate their individual and collective life. Bhargava (2013) suggests that there are many ways in which these injustices operate and provides two examples. The first occurs when dominant epistemic frameworks prevent one from having a secure knowledge of the historical and cultural traditions of one's own community: that is, the local epistemic framework of the group is either unavailable or may be present but unrecognisable as it has been scattered and diffused by the dominant framework. A second form is when the frameworks of the colonised group are still intact and exist as an option, but are rejected as worthless. In interfering with other cultures in such ways, colonialism distorted epistemic frameworks in accordance with the values of the colonisers. This distortion is diverse and develops differently in different contexts. Bhargava (2013) argues, similar to Nyamnjoh (2019) and Mamdani (2018) in the African context, that the academy plays a significant role in this new phase of (post) colonialism or what is called 'coloniality' above. In Bhargava's (2013) view, the modern Indian university has inherited and borrowed an array of practices and discourses from the colonisers, including a reliance on Western academic practice and theory, and have become ongoing transmitters of colonial power.

Turning to Africa, André Keet (2014) offers an insightful account, yet ultimately a rather pessimistic one, of epistemic injustice and why the decolonisation of 
knowledge is both complex and difficult. He concurs with Ndlovu-Gatsheni (2013) that 'the worst form of colonization ... on the continent is the epistemological one (colonisation of imagination and the mind)' (Ndlovu-Gatsheni 2013, cited in Keet 2014: 24), and indicates the complicity of academic disciplines and the higher education sector in Africa more generally. In analysing processes of knowledge and power, he examines how colonial knowledge became so dominant through 'epistemic othering', which denies or misrecognises epistemic identities of indigenous and colonised peoples. Thus Fricker's concept of epistemic injustice is inscribed into disciplinary formations of knowledge in the academy, which are constantly affirmed and reaffirmed through everyday acts of 'micro-othering' in research, teaching, and learning. Thus, such epistemic injustice is legitimised by the very mode of disciplining knowledge and largely rendered 'invisible to the academy itself' (Keet 2014: 24). Keet draws on Foucault's distinction between savoir and connaissance, where connaissance refers to disciplinary bodies of knowledge in scientific fields, while savoir is that underlying general knowledge which enables ('creates the conditions for') an object of knowledge to be taken up by a discipline, for example, in Foucault's own work, 'madness' as an object for study in psychiatry (2014: 24). Yet, for indigenous knowledge in Africa, these conditions created by savoir were insufficient for disciplinary formation due to colonial displacement. In other words, there was an absence of the necessary savoir. In turn, this has meant that African Studies, due to the 'brutal dislocation of savoir across the continent', has been tied to a Western base. In Keet's (2014: 24) words, 'it [African Studies] draws knowledge of Africa by African scholars on a Western canvass'. This absence of savoir, necessary for knowledge reformulations, largely accounts for the 'inertia and sterility of decolonization efforts over the past few decades' (2014: 31). But to continue the metaphor, Keet paints a rather bleak picture of structured determinism where colonial knowledge formations are so allembracing that, in his words, 'the decolonization of knowledge [is] a near impossible task' (2014: 25). However, Keet does argue for a new definitional framework for the decolonisation of knowledge with the possibility for innovative knowledge practices centred around epistemic justice and disrupting the disciplines, and calls for the academic resources and political courage to make this possible (2014: 35).

Pascah Mungwini (2017) also draws on the notion of epistemic injustice to conceptualise wrongdoing in knowledge production in Africa today, and adds historical and philosophical dimensions to the debates. He critiques the historic myth of emptiness and its consequences on Africa. He states 'African Know thyself' (Mungwini, 2017: 5), an urgent call to Africans to rise up and grasp the distinctive particularity of their history as a people of equal epistemic and ontological standing with the rest of humanity. For Mungwini, Africans must unwaveringly identify and pronounce their locus of enunciation - who they are and from where they speak. Mungwini (2017:11) 
argues that the ground for justifying the denial of the epistemic capabilities of the indigenous peoples of Africa had been laid before the colonial encounter. Through the work of influential scholars such as Hume, Kant, and Hegel, who denied the rationality of the African, a type of epistemic injustice is perpetuated as the African is denied their status and capacity as a bearer of knowledge. As colonialism instituted and sustains relations of dominance and subservience through most aspects of life, it also did so in the realm of knowledge production. Denying the epistemic status of the African, African traditions, and African forms of knowing are components of this colonial domination. Mungwini (2017: 12) captures the consequences of this domination:

Only rational beings can interpret the world around them, and since Africans were denied that ability, concepts had to be developed and donated to them in order to assist them to make sense of their reality. It is this injustice that today renders conceptual decolonisation an indispensable aspect of philosophical practice in Africa.

Mungwini demonstrates the unjust reasoning behind the rejection of the African knower, African traditions and African forms of knowing that led to their sustained marginalisation.

The focus here is on the historicity of the African existence, which maintains that the African experience should be the foundation from which one should seek to understand and interpret its politics, history, and philosophy (Ramose 2000). In his book titled Of Africa, Wole Soyinka (2012: 27) rightly challenges the colonial paradigm of 'discovery' and argued that Africa has always been there and is not a colonial creation. As Ndlovu-Gatsheni also states, Africans were always present (2018: 2). Wale Adebanwi (2016: 350) informs us that the question at the heart of intellectual thought and knowledge production in Africa is not so much about its 'independence' as it is about its 'originality'. According to Linda Tuhiwai Smith (1999: 28), this speaks to the attempt to rewrite and re-right Africa's position in history and in the process unsettle the paradigm within which epistemic injustice continues to thrive. A major consequence of the Eurocentric dominance has given rise to calls for epistemic freedom born out of epistemic injustice. Some even refer to this as 'dehumanisation' (Nabudere 2011), 'epistemicide' (Santos 2014), and 'epistemic violence' (Makgoba 1998, Heleta 2016).

The academic sector has witnessed increasing calls to champion the decolonisation of knowledge production within African universities (see Kamola, 2011, Táíwò, 2012, Mbembe, 2016, Molefe 2016, Shay 2016, Ndofirepi \& Gwaravanda, 2019). In his 2016 work that discusses colonial legacies within the African higher education system, Achille Joseph Mbembe (2016: 32) points to the centrality of the Eurocentric epistemic canon and the fact that syllabuses designed to meet the needs of colonialism and 
apartheid are continuing well into the liberation era, and this cannot be the accepted norm. Mbembe (2016: 33) calls for decolonisation as the Western has become hegemonic. The Western notion of academic knowledge production brings with it particular discursive scientific practices and interpretive frameworks, and it is difficult to think outside of these frames due to its hegemonic status. However, Mbembe's (2016: 33) argument goes even further as he argues that the Western hegemonic tradition also actively represses that which is articulated and thought of outside of the hegemonic framework. Mbembe (2016: 33) suggests that these are the reasons why a process of decolonisation, both of knowledge and of the university as an institution, is necessary. He cites the examples of present-day universities as large systems of authoritative control, standardisation, gradation, accountancy, classification, credits, and penalties. Mbembe (2016: 30) uses this to show the need to decolonise:

the systems of access and management that have turned higher education into a marketable product, rated, bought and sold by standard units, measured, counted and reduced to staple equivalence by impersonal, mechanical tests and therefore readily subject to statistical consistency, with numerical standards and units.

This form of decolonisation, he further explains, is necessitated due to its influence in discouraging both students and teachers from a free pursuit of knowledge while substituting the purpose of free pursuit of knowledge for another, the pursuit of credits.

\section{What can be done?}

Calls for the decolonisation of knowledge production in academia have intensified in recent years (see, for instance, the work of Mbembe 2016, Heleta 2016, NdlovuGatsheni 2018, Nyamnjoh 2019, Arowosegbe 2016), including in the humanities and social sciences. While the need for decolonising knowledge production is well established, there has been insufficient attention on how to achieve this in practice. In line with the above discussion about why decolonisation of knowledge production is necessary, here we outline possible measures to contribute to that process at two different levels. The first involves practical measures to increase the representation of Africa-based scholars in scholarly knowledge production, thus countering asymmetries and current injustices. The second set of measures entails a more fundamental reorientation of how knowledge is produced and the nature of knowledge on Africa, seeking to address current epistemic injustice. 


\section{Countering asymmetries}

A number of Northern-based journals and academic associations have attempted to address the under-representation of Africa-based researchers, and by extension those in the Global South more generally. Measures include writing workshops that provide practical support mostly to Africa-based early career researchers on academic writing and publishing. For example, the African Studies Association of the UK's writing workshop programme, in existence since 2009, offers academic mentorship to (mostly early career) scholars based in African institutions, and is organised in collaboration with African universities. The British Academy also provides funding for writing workshops some of which have been held in the Global South, including Ghana, Algeria, and Mexico that built capacities on academic writing focusing on high-impact international journals. Similarly, the journal African Studies Review, published by the African Studies Association (USA), holds Pipeline for Emerging African Studies Scholars (PEASS) Workshops to provide mentorship and develop high-quality journal submissions, although this is not limited to Africa-based scholars. Medie \& Kang (2018) made a range of recommendations for improving the representation of scholars from the Global South in high-ranking journals. They proposed to journal editors that journal submission rates be tracked by location, along with the encouragement of scholars from the Global South to submit manuscripts; to adopt and implement an editorial vision that promotes inclusion; and to extend invitations to scholars in the Global South to serve on editorial boards and as editors. They also asked professional organisations to sponsor research in the Global South; to sponsor writing workshops for such scholars; and to extend invitations for conference participation and workshops. Individual researchers were also encouraged to undertake cross-regional research collaborations (Medie \& Kang 2018: 45), although this also raises the question of equity and balance in these collaborations, ensuring that the Global South scholars are not reduced to mainly data collectors and excluded in major publications. Aimed at addressing the particularly low representation of African women within academia, the Merian Institute for Advanced Studies in Africa (MIASA) at the University of Ghana, has held a series of 'Female Academic Career' workshops in Dakar since 2018, including sessions on publishing and applying for research grants. ${ }^{3}$

While building the capacity of Africa-based scholars to publish internationally is clearly important, another approach is to encourage scholars in both the Global South and North to contribute to journals published by African universities, and hence enhance their status. Claude Ake was aware of the significance of Africa-based journals with the establishment of the African Journal of Political Economy in 1986,

${ }^{3}$ https://www.ug.edu.gh/mias-africa/content/female-academic-career-workshop 
and their role in the publication of endogenous research. Diana Jeater (2018: 25) comments that African scholars must make a choice "whether to accept and cultivate the dominant research culture of the North in order to get "thinking from the South" published in international journals; or whether to attempt to challenge that hegemony and establish parallel African journals and publishing houses outside the international high-IF [impact factor] rankings'. Arowosegbe (2016: 325) notes that a limited number of journals published by Nigerian universities, for example, are indexed in the Web of Science database, and that to increase this number would also require a commitment to publish therein of established African scholars in the diaspora. The Contemporary Journal of African Studies, based at the Institute of African Studies at the University of Ghana, is one journal that is increasingly recognised internationally for its strong contribution to African-centred scholarship.

Opportunities for academic conference attendance is another area of inequality, not least because major African Studies-related conferences are held in Europe and North America. To increase access for Africa-based researchers, some professional bodies such as the African Studies Association, the Association for African Studies in Germany (VAD), the European Conference on African Studies (ECAS), and the Development Studies Association (UK) are supporting conference attendance through full sponsorship. The European Association of Development Research and Training Institutes (EADI) also provides conference fee waivers to African and Asian scholars. While welcome, a major constraint for Africa-based scholars is getting visas to attend conferences, especially in the United Kingdom and the United States. The visa issue is something to be dealt with politically and legally as it remains as a major hindrance for equal participation and engagement at the international level for Global South scholars. Similar to the above discussion about journal publications, it is hardly radical to propose that African Studies conferences would be more appropriately located in Africa. The establishment in 2013 of the African Association of African Studies (ASAA) by various Centres and Institutes for African Studies at African universities, and the holding of its biannual conference, are important steps in promoting the advancement of research and knowledge production on African peoples and cultures on the continent itself. Recent developments with the COVID-19 global pandemic have led to a dramatic shift to virtual conference attendance via online platforms such as Zoom. Although this shift has provided more opportunities for scholars to participate without physical attendance, many scholars in the Global South remain constrained by inadequate electrical power supply and unstable internet connectivity. Therefore, going forward into an online future, it is evident that challenges remain to engagement on an equal footing between scholars based in the Global South and Global North. 


\section{Towards epistemic justice?}

Important as such measures and developments are in countering asymmetries in access to and production of knowledge on Africa, as well as in questioning the power dynamics between researchers and institutions in the Global North and South, they do not necessarily amount to a decolonisation of knowledge, as such. To address current epistemic injustices and their links to coloniality, a more radical questioning of epistemological approaches is required.

To create a properly informed setting for decolonising knowledge entails the need to take a step back and critically re-examine strategies that would disrupt the norms in terms of how knowledge is produced within our view of the world and the space we occupy within it. To unsettle the paradigm, we have to 'rethink thinking' (NdlovuGatsheni, 2018: 23) which Lewis Gordon (2006) declared as 'shifting the geography of reason' and entails a number of decolonial moves. Rethinking thinking acknowledges the cultural asphyxiation of those numerous 'others', the generally accepted norm, and strives to bring other categories of self definition, of dreaming, of acting, of loving, of living into the commons as matter of universal concern (Hoppers \& Richards, 2012: 8). The emphasis here is on the experiences and actions of the relatively powerless, which favours scrutinising power from the bottom up and the identification of the ways through which knowledge production could be used to contribute to reflection on power relationships. As a decolonial move, rethinking thinking is informed by a clear-cut principle that all human beings are not only born into a knowledge system, but are legitimate knowers and producers of knowledge (NdlovuGatsheni 2018). Tlostanova and Mignolo (2012: 12) argue for a system of 'learning to un-learn in order to re-learn' which includes opening to other knowledges and thinkers beyond the dominance of those from Europe and North America. Radical departures from the existing norms can be quite challenging and are never easy, but they open up novel avenues for questioning what was once unquestioned and unquestionable (Msimang 2015). This opens us to a process of 'learning to unlearn' through 'forgetting what we have been taught, to break free from the thinking programs imposed on us by education, culture, and social environment, always marked by the Western imperial reason' (Tlostanova and Mignolo 2012: 7).

The situated nature of knowledge, the wish to create non-hierarchical knowledge, and an orientation towards emancipatory action (Enria 2016) form part of these concerns. The reinvention of social emancipation within knowledge production is premised upon replacing what Boaventura de Sousa Santos $(2003,2004)$ calls the 'monoculture of scientific knowledge' by an 'ecology of knowledges'. This 'ecology of knowledges' is open to the promotion of non-relativistic dialogues among knowledges, granting 'equality of opportunities' to the different kinds of knowledge engaged 
in even broader epistemological disputes aimed both at maximising their respective contributions to decolonising knowledge and power and building a more democratic and just society (Santos 2007, Smith 2012). In more recent work, Santos (2014, 2016, 2018) introduced the term 'Epistemologies of the South' and dramatically juxtaposed these to 'Epistemologies of the North'. While the latter epitomise the classical positivist approach to knowledge that portrays itself as scientific, neutral, an objective representation of reality, and the only source of valid knowledge, for Santos 'Epistemologies of the North' are the supposedly 'scientific knowledge' that along with economic and military power enabled imperial domination, with some echoes here of Ake (1982). In strong terms, Santos states that 'Epistemologies of the North' entail the hegemonic knowledge that legitimates oppression and reproduces capitalism, colonialism, and patriarchy. Santos makes the point that Epistemologies of the North can also flourish in the geographical South. In contrast, 'Epistemologies of the South' respond to the coloniality of knowledge and therefore the need to retrieve silenced and marginalised knowledges. Thus, Epistemologies of the South enable oppressed social groups to represent the world in their own terms, as part of struggles of resistance against oppression and the knowledge that legitimates it. It entails opening up to new forms of knowledge and understanding in which the voices and perceptions of marginalised people and communities are central.

Ndlovu-Gatsheni (2018: 1) calls for complete epistemic freedom, away from the long-term consequences of modernity, enslavement, and colonialism, which subjugated Africans as agents in a Eurocentric history. Epistemic freedom underscores the right to think, theorise, interpret the world, develop one's own methodologies and write from where one is located, unencumbered by Eurocentrism (Ndlovu-Gatsheni 2018: 3). This requires the genuine acknowledgement and acceptance of the contribution of the indigenous people of Africa to knowledge generation, and involves the significant presence of their knowledge paradigms in the formal education curriculum, presently dominated by Western knowledge paradigms (Masaka 2019: 298; see also Fricker 2007). However, Dennis Masaka (2019) defends a more demanding view than just ensuring coexistence of diverse knowledge paradigms in formal education. Rather, epistemic justice, for Masaka, entails a more substantive decolonisation and transformation of the curriculum that ought to focus on empowering learners to take the lead in tackling the challenges that African countries face today. Thus, he is suggesting that the recognition and acceptance of indigenous knowledge paradigms are necessary steps toward epistemic justice, but not the end goal in itself.

Mbembe explains that African universities must undertake decolonisation both of knowledge and of the university as an institution (Mbembe, 2016: 33). He argues that more needs to be done in order to achieve this. He puts forward a two-sided approach that, first, fights the 'epistemic coloniality' in terms of critiquing the dominant 
Eurocentric model; and, second, to start imagining what the alternative model would look like (2016: 36). Mbembe relates this to what Ngugi wa Thiong'o (1986; cited as 1981 in Mbembe 2016: 34) termed a new struggle over the educational content to be taught to the African child and the terms under which African children should be taught (2016: 35). Such a move would bring an end to the university system as we know it and give rise to what Mbembe (2016: 36) calls 'pluriversity' (also see Santos 2018), a knowledge production process that is receptive to epistemic diversity via a horizontal strategy of openness to dialogue among different epistemic traditions. One question Mbembe posed was the issue of timing and whether the university is reformable (2016: 37)? Can universities shift away from the Eurocentric 'epistemic canon' model (Mbembe, 2016: 32)?

Similarly, Amasa Philip Ndofirepi and Ephraim Taurai Gwaravanda (2019: 325) have called for dialogue among the diverse forms of knowledge, but this could be problematic in a situation where the dominant force is not favourably disposed to engaging in dialogue. Dialogue helps to extend the horizon of possibilities and signifies a key component of constant renovation of knowledge more in terms of cognitive justice and the recognition of diverse ways of knowing by which human beings across the globe make sense of their existence. Thus, dialogue helps to broaden the landscape of research possibilities (Ordorika 1999) and signifies a key component of constant renovation of knowledge.

To reform, African universities must open up 'to different bodies and traditions of knowledge and knowledge-making in new and exploratory ways' (Heleta 2016: 2 ), in other words, the universities have to embark on a process of rethinking, reframing, and reconstructing. Keet et al. (2017) directly discuss the means to turn decolonial rhetoric into practice. Starting by bringing African decolonial thinking into conversation with the Latin American decoloniality network and Asian postcolonial scholars, they suggest greater linkages with other critical theories, notably feminist theory, queer theory, critical race theory, and so on. In his view, this could create a colloquy of critical theories and practices to explore and critique the power mechanics of institutions with a commitment to create a more socially just academia (Keet et al. 2017).

Since decolonisation entails 'deconstruction and reconstruction' (see Smith 1999, Chilisa 2012: 17), we argue for a decolonial methodological framework in research which is more than a political goal: it is a goal of social justice expressed through and across a wide range of psychological, social, cultural, and economic terrains (Smith, 1999, 2008). Research should be a platform that enables those who have suffered long histories of oppression and marginalisation to be provided with a space to communicate their world-views and experiences (Chilisa 2012). The emphasis is the way in which knowledge is acquired or discovered and as a way in which we can 'know' what 
is real (Smith, 1999, 2008). Participatory approaches/methodologies have long been advocated as means to generate knowledge that addresses power inequalities, passing power from researcher(s) to research participants (Chambers 1997) and endorsing diverse perspectives of social realities as endogenous knowledge. While critiques were rightly made of the shortcomings of participatory discourse (Cooke \& Kothari 2001), we assert that participatory approaches retain transformatory potential (Hickey \& Mohan 2004). In many instances, advocates for the decolonisation of knowledge production and for participatory methodologies share a common critique of conventional/mainstream knowledge and an intent to validate a variety of forms of knowledge.

Participatory research as decolonising knowledge can lead to qualitative changes in power relations both in the research process and in generating endogenous knowledge that highlights marginalised perspectives and challenges structures of injustice. This might include expanding possibilities for intercultural dialogue and enabling more equitable research collaborations to occur. Ways of producing knowledge on the Global South require a critical review of research methods and theories that enable non-hegemonic viewpoints, approaches, and voices to enter the conversation. The use of participatory methods entails certain advantages related with the process of collectively undertaking and generating research findings. Vulnerable communities can understand the research process, why research is needed, and ultimately how it can be produced together, thereby dismantling the traditional hierarchy between researcher and participant-as-researcher and transformed into a space where all knowledge is valued and heard (Martin et al. 2019). However, various challenges arise in participatory research which need to be addressed. For example, tensions between those directly involved in the area of research and others less directly involved and their relative power in the actual process arise when working on issues revolving around dismantling binaries, such as Global North and South, gender, race, sexuality, and other forms of identity. Power inequalities silence some, while amplifying the voices of others. Therefore, a careful balancing of competing priorities and negotiating common positions through participatory methodologies is required in order to serve as important aspects of knowledge production in social science research (Yeates \& Amaya 2014). Therefore, focus should be on methodologies and tools that will develop a more power-conscious practice and explore pedagogies that focus on the transformation of power relations. 


\section{Conclusion}

This article has examined the issue of decolonising knowledge production in the humanities and social sciences, with a particular focus on Africa. This issue is currently highly visible and controversial in higher education institutions globally. Calls to decolonise education processes arose in the wake of the challenge to universities that emerged with the 'Rhodes must fall' movement and associated student protests in South Africa in 2015, including the subsequent waves of protest around the world, including in the UK.

Our starting point was to note that this contemporary debate is not new, unsurprisingly given that political independence in most of sub-Saharan Africa occurred over sixty years ago. We highlighted how Nkrumah, as first president of Ghana and pan-Africanist, established the Institute of African Studies at the University of Ghana with a decolonial mandate to generate Africa-centred knowledge that distinguished itself from 'European studies of Africa'. We noted how prominent African social scientists, such as Claude Ake in the 1980s, resisted the dominance of Western theories and paradigms in explaining African phenomena. Yet, despite these important precedents, the failure to fully decolonise knowledge production remains as a critical impediment that limits understanding of African societies and cultures. Thus, we have explored why it remains necessary and what can be done to pursue such decolonisation within the context of scholarly research.

Our proposition is that these questions can be addressed at different levels, and we have highlighted a more practical level and a more reflexive level concerning the nature of knowledge production. At both levels, issues of power inequalities and injustice are key. At the more concrete and practical level, we highlighted the asymmetrical power relations between scholars in the Global North and South in research activities and the marginalisation of African scholarship in leading journals. We outlined potential ways in which such asymmetries could be challenged and countered: for instance, through greater equity in research collaboration and greater inclusion of Africa-based scholars as editors/editorial board members of leading journals on Africa. However, although desirable, such measures are insufficient. There remains the deeper level of the type of knowledge produced by Western-centric epistemologies. We have outlined the reflections and analysis of a number of contemporary African and other authors, all striving to contest the ongoing coloniality and epistemic injustices that continue to influence knowledge production on Africa and elsewhere in the Global South. Thus, decolonisation is complex and difficult and calls for a more fundamental reorientation of ontological, epistemological, and methodological approaches. It requires such profound measures as 'rethinking thinking' (Ndlovu-Gatsheni 2018) in order to unsettle dominant Eurocentric paradigms, and a shift to developing 'ecologies of 
knowledge' and 'Epistemologies of the South' (Santos 2007, 2014) to (re)discover alternative ways of understanding the world, notably through listening to excluded and marginalised voices. Finally, in terms of an appropriate decolonising methodology, we suggest that advocates for the decolonisation of knowledge production and for participatory approaches share a common critique of mainstream knowledge and an intent to generate endogenous knowledge that highlights marginalised perspectives and challenges structures of injustice. This is an area for further research in the crucial struggles to decolonise knowledge production on Africa and elsewhere.

\section{References}

Adebanwi, W. (2016), 'Rethinking Knowledge Production in Africa', Africa: The Journal of the International African Institutes, 86(2): 350-3. https://doi.org/10.1017/S0001972016000115

Ake, C. (1982), Social Science as Imperialism: The Theory of Political Development (Ibadan, Ibadan University Press).

Ake, C. (1986), 'Editorial: Raison D'etre', African Journal of Political Economy / Revue Africaine d'Economie Politique, 1(1, Southern Africa In Crisis): II-IV.

Allman, J. (2013), 'Kwame Nkrumah, African Studies, and the Politics of Knowledge Production in the Black Star of Africa', International Journal of African Historical Studies, 46(2): 181-203.

Arowosegbe, J.O. (2008a), 'Decolonising the Social Sciences in the Global South: Claude Ake and the Praxis of Knowledge Production in Africa' (Working Paper 79/2008; Leiden, African Studies Centre).

Arowosegbe, J.O. (2008b), 'The Social Sciences and Knowledge Production in Africa: The Contribution of Claude Ake', Africa Spectrum, 43(3): 333-51

Arowosegbe, J.O. (2016), 'African Scholars, African Studies and Knowledge Production on Africa', Africa, 86(2): 324-38. https://doi.org/10.1017/S0001972016000073

Bhargava, R. (2013), 'Overcoming the Epistemic Injustice of Colonialism', Global Policy, 4(4): 413-17. https://doi.org/10.1111/1758-5899.12093

Briggs, R.C. \& Weathers, S. (2016), 'Gender and Location in African Politics Scholarship: The Other White Man's Burden?', in African Affairs, 115(460): 466-89. https://doi.org/10.1093/afraf/adw009

Chambers, R. (1997), 'Shortcut and Participatory Methods for Gaining Social Information for Projects' (San José, Costa Rica, Inter-American Institute for Co-operation on Agriculture).

Chilisa, B. (2012), Indigenous Research Methodologies (Los Angeles, CA, London and New Delhi, Sage).

Cooke, B. \& Kothari, U. (eds) (2001), Participation: The New Tyranny? (London, Zed Books).

Enria, L. (2016), 'Co-producing Knowledge through Participatory Theatre: Reflections on Ethnography, Empathy and Power', Qualitative Research, 16(3): 319-29. https://doi.org/10.1177/1468794115615387

Fricker, M. (2007), Epistemic Injustice: Power and the Ethics of Knowing (Oxford, Oxford University Press). https://doi.org/10.1093/acprof:oso/9780198237907.001.0001

Gordon, L.R. (2006), 'Foreword', in M.P. Banchetti-Robino \& C.R. Headley (eds) Shifting the Geography of Reason: Gender, Science and Religion (Newcastle, Cambridge Scholars Press).

Grosfoguel, R. (2007), 'The Epistemic Decolonial Turn: Beyond Political-economy Paradigms', Cultural Studies, 21(2-3): 203-26. https://doi.org/10.1080/09502380601162514 
Heleta, S. (2016), 'Decolonisation of Higher Education: Dismantling Epistemic Violence and Eurocentrism in South Africa', Transformation, 1(1): a9. https://doi.org/10.4102/the.v1i1.9.

Hickey, S. \& Mohan, G. (eds) (2004), Participation-From Tyranny to Transformation: Exploring New Approaches to Participation in Development (London, Zed Books).

Hoppers, C.O. \& Richards, H. (2012), Rethinking Thinking: Modernity's 'Other' and the Transformation of the University (Pretoria, UNISA Press).

Hountodji, P. (ed.) (1997), 'Introduction: Recentering Africa', in P. Hountodji (ed.) Endogenous Knowledge: Research Trails (Dakar, Codesria Book Series), 1-39.

Jeater, D. (2018), 'Academic Standards or Academic Imperialism? Zimbabwean Perceptions of Hegemonic Power in the Global Construction of Knowledge', African Studies Review, 61(2): 8-27. https://doi.org/10.1017/asr.2017.132

Kalinga, C. (2019), 'Caught Between a Rock and a Hard Place: Navigating Global Research Partnerships in the Global South as an Indigenous Researcher', Journal of African Cultural Studies, 31(3): 270-2. https://doi.org/10.1080/13696815.2019.1630261

Kamola, I.M. (2011), 'Pursuing Excellence in a "World-class African University": The Mamdani Affair and the Politics of Global Higher Education', Journal of Higher Education in Africa, 9(1/2): $147-68$.

Keet, A., Sattarzadeh, S.D. \& Munene, A. (2017), 'An Awkward, Uneasy (De) Coloniality: Higher Education and Knowledge Otherwise', Education as Change, 21(1): 1-12. https://doi.org/10.17159/1947-9417/2017/2741

Kidd, I.J., Medina, J. \& Pohlhaus Jr., G. (eds) (2017), 'Introduction', in Routledge Handbook of Epistemic Injustice (Abingdon, Routledge), 1-10. https://doi.org/10.4324/9781315212043-1

Kwesi Yankah, (1995), 'Displaced Academies and the Quest for a New World Academic Order', Africa Today, 42(3): 7-25.

Makgoba, M. (1998), 'South African Universities in Transformation: An Opportunity to Africanise Education', in S. Seepe (ed.) Black Perspectives on Tertiary Institutional Transformation (Florida, Vivlia Publishers), 42-62.

Maldonado-Torres, N. (2007), 'On the Coloniality of Being: Contributions to the Development of a Concept', Cultural Studies, 21(2-3): 240-70. https://doi.org/10.1080/09502380601162548

Mama, A. (2002), 'Editorial, Feminist Africa', Intellectual Politics, 1. http://www.agi.ac.za/sites/default/ files/image_tool/images/429/feminist_africa_journals/archive/01/fa_1_editorial.pdf

Mama, A. (2007), 'Is It Ethical to Study Africa? Preliminary Thoughts on Scholarship and Freedom'. African Studies Review, 50(1): 1-26. https://doi.org/10.1353/arw.2005.0122

Mamdani, M. (1992), 'Africa: Democratic Theory and Democratic Struggles', Economic and Political Weekly, 27(41): 2228-32.

Mamdani, M. (1996), Citizen and Subject: Contemporary Africa and the Legacy of Late Colonialism (Princeton, NJ, Princeton University Press). https://doi.org/10.1086/ahr/102.5.1541

Mamdani, M. (2007), Scholars in the Market Place: The Dilemmas of Neo-liberal Reform at Makerere University, 1989-2005 (Dakar, CODESRIA Books).

Mamdani, M. (2011), 'The Importance of Research in a University', Pambazuka News, 21 April, 526.

Martin, S.B., Burbach, J.H., Benitez, L.L. \& Ramiz, I. (2019), 'Participatory Action Research and Co-Researching as a Tool for Situating Youth Knowledge at the Centre of Research', London Review of Education, 17(3): 297-313. https://doi.org/10.18546/LRE.17.3.05

Masaka, D. (2019), 'Attaining Epistemic Justice Through Transformation and Decolonisation of Education Curriculum in Africa', African Identities, 17(3-4): 298-309. https://doi.org/10.1080/14725843.2019.1681259

Mbembe, J. (2016), 'Decolonizing the University: New Directions', Arts \& Humanities in Higher Education, 15(1): 29-45. https://doi.org/10.1177/1474022215618513 
Medie, P.A. \& Kang, A.J. (2018), Power, Knowledge and the Politics of Gender in the Global South, European Journal of Politics and Gender, 1(1-2): 37-54. https://doi.org/10.1332/251510818X15272520831157

Molefe, T.O. (2016), 'Oppression Must Fall: South Africa's Revolution in Theory', World Policy Journal, 33(1): 30-7. http://doi.org/10.1215/07402775-3545858

Msimang, S. (2015), 'The Old is Dying and the Young Ones Have Just Been Born', Africa is a Country, 15 May.

http://africasacountry.com/2015/05/the-old-is-dying-and-the-young-ones-have-just-been-born/ [accessed 2 July 2016]

Mudimbe, V.Y. (1988), The Invention of Africa: Gnosis, Philosophy, and the Order of Knowledge (Bloomington, IN, Indiana University Press).

Mudimbe, V.Y. (1994), The Idea of Africa (Bloomington, IN, Indiana University Press). https://doi.org/10.1086/ahr/101.3.883

Mungwini, P. (2017), “African Know Thyself”: Epistemic Injustice and the Quest for Liberative Knowledge', International Journal of African Renaissance Studies - Multi-, Inter- and Transdisciplinarity, 12(2): 5-18. https://doi.org/10.1080/18186874.2017.1392125

Nabudere, D.W. (2011), Afrikology: Philosophy and Wholeness: An Epistemology (Pretoria, Africa Institute of South Africa).

Ndlovu-Gatsheni, S.J. (2013), Coloniality of Power in Postcolonial Africa: Myths of Decolonization (Oxford, African Books Collective).

Ndlovu-Gatsheni, S.J. (2018), Epistemic Freedom in Africa: Deprovincialization and Decolonization (Abingdon, Routledge). https://doi.org/10.4324/9780429492204

Ndlovu-Gatsheni, S.J. (2020), 'The Cognitive Empire, Politics of Knowledge and African Intellectual Productions: Reflections on Struggles for Epistemic Freedom and Resurgence of Decolonisation in the Twenty-first century', Third World Quarterly. https://doi.org/10.1080/01436597.2020.1775487

Ndofirepi A.P. \& Gwaravanda E.T. (2019), 'Epistemic (In)justice in African Universities: A Perspective of the Politics of Knowledge', Educational Review, 71(5): 581-94. https://doi.org/10.1080/00131911.2018.1459477

Ngugi wa Thiong'o, (1986), Decolonising the Mind: The Politics of Language in African Literature (Oxford, James Currey).

Nkrumah, K. (1973), Revolutionary Path (London, PANAF Books).

Nyamnjoh, F.B. (2004), 'A Relevant Education for African Development-Some Epistemological Considerations', Africa Development, 29(1): 161-84. https://doi.org/10.4314/ad.v29i1.22190

Nyamnjoh, F.B. (2012), "Potted Plants in Greenhouses": A Critical Reflection on the Resilience of Colonial Education in Africa', Journal of Asian and African Studies, 47(2): 129-54. https://doi.org/10.1177/0021909611417240

Nyamnjoh, F.B. (2017), Drinking from the Cosmic Gourd: How Amos Tutuola Can Change Our Minds (Bamenda, Langaa Research and Publishing CIG). https://doi.org/10.2307/j.ctvh9vw76

Nyamnjoh, F.B. (2019), 'Decolonizing the University in Africa', in Oxford Research Encyclopedia of Politics (Oxford, Oxford University Press).

https://doi.org/10.1093/acrefore/9780190228637.013.717

Ordorika, I. (1999), 'Power, Politics and Change in Higher Education: The Case of the National Autonomous University of Mexico', PhD Thesis, Stanford University.

Ramose, M. B. (2000), “'African Renaissance”: A Northbound Gaze', Politeia, 19(3): 47-61.

Said, E.W. (1978), Orientalism: Western Conceptions of the Orient (London, Routledge and Keegan Paul).

Santos, B. de S. (2003), 'The World Social Forum: Toward a Counter-hegemonic Globalization', in Sen, Jai, Anand, Anita, Escobar, Arturo \& Waterman, Peter (eds) World Social Forum. Challenging Empires (New Delhi, The Viveka Foundation), 336-43. 
Santos, B. de S., (2004), 'A Critique of Lazy Reason: Against the Waste of Experience', in I. Wallerstein (ed.) The Modern World System in the Longue Durée (London, Paradigm Publishers), 157-97.

Santos, B. de S., (2007), 'Beyond Abyssal Thinking: From Global Lines to Ecologies of Knowledges', Review, 30(1): 45-89.

Santos, B. de S. (2014), Epistemologies of the South: Justice Against Epistemicide (Boulder, CO, and London, Paradigm). https://doi.org/10.4324/9781315634876

Santos, B. de S. (2016), 'Epistemologies of the South and the Future', From the European South: A Transdisciplinary Journal of Postcolonial Humanities, 1: 17-29.

Santos, B. de S. (2018), The End of the Cognitive Empire: The Coming of Age of Epistemologies of the South (Durham, NC, and London, Duke University Press). https://doi.org/10.1215/9781478002000

Shay, S. (2016), 'Decolonising the Curriculum: It's Time for a Strategy', The Conversation, 13 June. https://theconversation.com/decolonisingthe-curriculum-its-time-for-a-strategy-60598 [accessed 15 July 2016].

Smith, L.T. (1999), Decolonizing Methodologies: Research and Indigenous Peoples (London and New York, Zed Books).

Smith, L.T. (2008), Decolonizing Methodologies: Research and Indigenous People (London, Zed Books).

Smith, L.T. (2012), Decolonizing Methodologies, 2nd edn (London and New York, Zed Books).

Soyinka, W. (2012), Of Africa (New Haven, CT, and London, Yale University Press).

Táíwò, O. (2012), 'What is "African Studies"? African Scholars, Africanist Scholars, and the Production of Knowledge', in H. Lauer \& K. Anyidoho (eds) Reclaiming the Human Sciences and Humanities Through African Perspectives: Volume II (Accra, Sub-Saharan Publishers).

Tlostanova, M.V. \& Mignolo, W.D. (2012), Learning to Unlearn: Decolonial Reflections from Eurasia and the Americas (Columbus, OH, The Ohio State University Press).

Wylie, A. (2011), 'Epistemic Justice, Ignorance, and Procedural Objectivity-Editor's Introduction', Hypatia, 26(2): 233-5. https://doi.org/10.1111/j.1527-2001.2011.01179.x

Yeates, N. \& Amaya, A.B., (2014), Participatory Action Research: New Uses, New Contexts, New Challenges, PRARI Working Paper 15-6.

https://www.open.ac.uk/socialsciences/prari/files/working_paper_6_en.pdf

Zeleza, P.T. (2002), 'The Politics of Historical and Social Science Research in Africa', Journal of Southern African Studies, 28: 9-23. https://doi.org/10.1080/03057070120116953

Notes on the authors

Gordon Crawford is Research Professor in Global Development at the Centre for Trust, Peace and Social Relations, Coventry University. He is also Honorary Professor, University of Freiburg, and formerly (until December 2020) Director (Germany) of the Merian Institute for Advanced Studies in Africa (MIASA) at the University of Ghana. His work focuses on issues of human rights and democracy, often with fieldwork in Ghana. Recently he has explored issues of natural resource governance, especially in relation to small-scale gold mining in Ghana. He is currently undertaking research with Cameroonian colleagues on Cameroon's Anglophone conflict, with the aim of highlighting the voices of most-affected civilians.

ac1221@coventry.ac.uk 
Karl Landström is a PhD student at the Centre for Trust, Peace and Social Relations at Coventry University. His research interests lie primarily in the ethics of knowledge production. More specifically his doctoral research explores the intersection of postand decolonial theory and epistemic injustice, specifically as it pertains to academic knowledge production.

landstrk@uni.coventry.ac.uk

Zainab Mai-Bornu is a Research Fellow at the Centre for Trust, Peace and Social Relations, Coventry University. She is also a visiting Research Fellow at the Centre for Development Studies, University of Bath. Her work focuses on resources, conflict, gender, and development. Funded by the Economic and Social Research Council, her recent project, 'Bringing Women's Voices Back in: Gender and Oil Conflict in the Niger Delta', highlights the comparative roles of women in conflict settings. Much of her current work is concerned with amplifying marginalised voices within the context of vernacular security.

ad3701@coventry.ac.uk

To cite the article: Gordon Crawford, Karl Landström and Zainab Mai-Bornu (2021), 'Decolonising knowledge production on Africa: why it's still necessary and what can be done', Journal of the British Academy, 9(s1): 21-46.

DOI https://doi.org/10.5871/jba/009s1.021

Journal of the British Academy (ISSN 2052-7217) is published by

The British Academy, 10-11 Carlton House Terrace, London, SW1Y 5AH

www.thebritishacademy.ac.uk 